\title{
Interleukins in Periodontal Health and Disease
}

\author{
Babitha GA ${ }^{1}$, Disha Nagpal ${ }^{2}$, Snehal J Shripad ${ }^{3}$, \\ Shiva Charan Yadav ${ }^{4}$, Shobha Prakash ${ }^{5}$
}

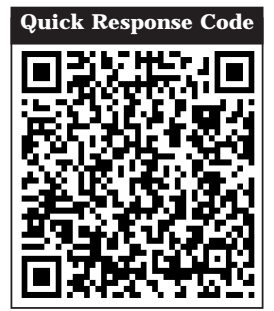

doi: $10.5866 / 2016.8 .10018$

1,2,3,4\&5 Department of Periodontics

College of Dental Sciences,

Davangere, Karnataka, India

\section{Article Info:}

Received: J anuary 9, 2016

Review Completed: February 12, 2016

Accepted: March 11, 2016

Available Online: May, 2016 (www.nacd.in)

(C) NAD, 2016 - All rights reserved

\section{Email for correspondence:}

shivacharan08@gmail.com

\begin{abstract}
:
Periodontal diseases, a series of infections of the periodontal tissues which eventually can lead to loss of teeth, are form of aberrant inflammation. The rel ease of inflammatory mediators and cytokines as local host response to the periodontopathic bacteria appears to play crucial role in the pathogenesis of periodontal diseases Interleukins are a large group of immunomodulatory proteins that elicit a wide variety of responses in cells and tissues. Interleukins function in a paracrine or autocrine fashion, rather than as an endocrine signal, which is more common with steroidal and amino acidderived hormones. Thus, the investigation of interleukins responses to periodontal diseases is at the forefront of the translational research agenda in oral science. This review summarizes interleukin expression in periodontal tissues and its importance in tissue homeostasis and, in particular, in the pathogenesis of periodontal diseases.
\end{abstract}

Key words: I nterleukins, Periodontitis, cytokines, mediators, pathogenesis

\section{INTRODUCTION}

Periodontal diseases, a series of infections of the periodontal tissues which eventually can lead toloss of teeth, are form of aberrant inflammation. ${ }^{1}$ The release of inflammatory mediators and cytokines as local host response to the periodontopathic bacteria appears to play crucial roles in the pathogenesis of periodontal diseases. ${ }^{1}$ Many biological events are strictly regulated by cell-cell interactions, which may be either cognate (adhesive) interactions, achieved by membrane-bound cell-surface molecules; or cytokine-mediated interactions. Cytokines aresmall soluble proteins produced by a cell that alter the behavior or properties of another cell locally or systemically in an autocrine or paracrine manner. They are pleiotropic molecules and most of them are multifunctional. Cytokines are involved in extensive networks that involve synergistic as well as antagonistic interactions and exhibit both negative and positive regulatory effects on various target cells. ${ }^{1}$ These play an important role in numerous biological activities including proliferation, development, differentiation, homoeostasis, regeneration, repair and inflammation. ${ }^{2}$

Thus, the investigation of interleukins responses to periodontal diseases is at the for efront of the translational research agenda in oral science. This review summarizes interleukin expression in 
periodontal tissues and its importance in tissue homeostasis and, in particular, in the pathogenesis of periodontal diseases.

Interleukins are a large group of immunomodulatory proteins that elicit a wide variety of responses in cells and tissues. I nterleukins initiate a response by binding to high-affinity receptors located on the surface of cells; I nterleukins function in a paracrine or autocrine fashion, rather than as an endocrine signal, which is more common with steroidal and amino acid-derived hormones. The response of a particular cell to these cytokines depends on the ligands involved, specific receptors expressed on the cell surface and the particular signalling cascades that are activated. I Ls modulate growth, differentiation and activation during an immune response. This distinguishes them from chemokines - the main function of which is to direct immune cells to the site of inflammation via chemotaxis - and interferons (IF Ns), which predominantly mediate cellular response to viral infection.

\section{The Nomenclature of Interleukins}

The term interleukin derives from (inter-) "as a means of communication", and (-leukin) "deriving from the fact that many of these proteins are produced by leukocytes and act on leukocytes". The term interleukin was coined by Dr. Paetkau, University of Victoria. Being non-structural proteins, biological properties were and still are the gold standards for defining a cytokine. The interleukin nomenclature was invented to deal with the issue of multiple biological properties of cytokines. At the time of naming these molecules with an interleukin number, primary amino acid sequences of the active molecules were not known. But the nomenclature did nothing to resolve the broader issue of multiple biological properties ascribed to a single molecule. ${ }^{3}$

\section{Classification of Cytokines}

The local host response to the oral pathogens capable of causing periodontal disease includes the recruitment of leukocytes and the subsequent release of inflammatory mediators and cytokines, which appear to play crucial roles in the pathogenesis of periodontal diseases. ${ }^{2,4}$ Cytokines are generally classified by their ability promote or inhibit inflammatory responses. ${ }^{5}$ The classification of cytokines is shown in. An inflammatory cytokine is defined as a cytokine which is induced during the course of an inflammatory response and is closely associated with its onset and/or progression. Thus far, IL-Ia, IL-113, IL-6, 1L-8, and TNI-7-7 are generally classified as inflammatory cytokines. ${ }^{5}$

\section{INTERLE UKINS \\ INVOLVED \\ I N INFLAMMATION}

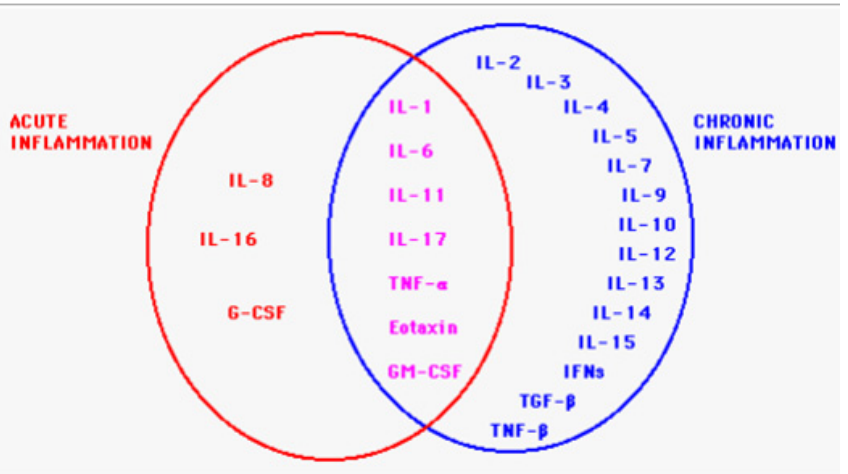

\section{CYTOKINES V/S CHEMOKINES}

The term chemokines, a short form of 'chemotactic cytokines', was coined in 1992. All the 50 or so human chemokines that were discovered over the years have chemo-tactic activity. They constitute a large family of mediators of inflammation and immunity with similarity to cytokines, but also some clear differences. Like cytokines the chemokines are secretory proteins produced by leucocytes and tissues cells either constitutively or after induction, and exert their effects locally in paracrine or autocrine fashion.

\section{Interleukin Expression in Gingival and Periodontal Health}

Tissue homeostasis represents a delicate balance between anabolic and catabolic activities. The regulations of migration, proliferation and differentiation of resident cells and of the production of tissue matrix in a healthy state are major aspects of periodontal tissue homeostasis. There is abundant evidence that myriad cytokines are involved in the maintenance of periodontal tissue turnover or integrity. ${ }^{2}$

\section{E pithelium}

The epithelium plays an active role in the pathogenesis of inflammation The gingival epithelium consists of keratinocytes, Langerhans 
cells, T-cells, Merckel cells and melanocytes. ${ }^{3}$ Keratinocytes, when challenged, with bacterial infection, express a large variety of cytokines and growth factors including interleukin-1 al pha (I L-1a), interleukin-8 (IL-8), tumor necrosis factor-al pha (TNF-a) and platelet-derived growth factor(PDGF). However, it is unknown whether cytokines and growth factors expressed by gingival epithelium are released in amounts sufficient to regulate remodeling in connective tissues of the periodontium. ${ }^{6}$

\section{Connective tissue (fibroblast)}

The dominant cell types are fibroblasts in the gingiva and fibroblast-like cells (called periodontal ligament cells) in the periodontal ligament. These cells express a variety of membrane and intracellular receptors, making the cells sensitive to regulate by many physiological and pathological, paracrine and endocrine signaling molecules. ${ }^{6}$ During inflammation, resident gingival fibroblasts are triggered by cytokines( released by macrophages) to enhance their synthesis of cytokines. IL-1 is the most potent regulator of extracellular matrix turnover by enhancing the expression of several matrix metalloproteinase. Interleukin-1 beta (I L-1b) and TNF -a stimulate the expression and release of interleukin-6 (IL-6), leukemia inhibitory factor and Interleukin-11 (IL11) in human gingival fibroblasts. ${ }^{8}$

Interleukins play a major role in initiation and progression of inflammatory process. However, a variety of different interleukins are involved in acute inflammation. These are summarized in Table 2

\section{Interleukins Involved in Chronic Inflammation}

Chronic inflammation may develop following acute inflammation and may last for weeks or months, and in some instances for years.

The detailed description of interleukins involved in Chronic Inflammation is shown in Table 4.

\section{EVIDE NCE}

A variety of studies have been conducted to elicit the function and structure of interleukins. These are summarized in Table 5.

Role of Interleukins in Pathogensis of Gingival Diseases

\section{Gingival Enlargement ${ }^{9}$}

Phenytoin drug is used for treatment of epilepsy.It reacts with phenotypically distinct subpopulation of gingival fibroblast and cause an increase in protein synthesis and cell proliferation rate. ILI and 6 found in higher levels in gingival crevicular fluid in phenytoin induced gingival over growth. It is suggested that this interleukin play indirect role in complex mechanism of phenytoin induced gingival over growth. ${ }^{9}$

\section{Role of Interleukins in Pathogenesis of Periodontal Diseases}

IL- I is known to stimulate the proliferation of keratinocytes, fibroblasts, and endothelial cells in an autocrine or paracrine fashion, and to enhance fibroblast synthesis of type I procollagen, collagenase, hyaluronate, fibronectin, and prostaglandin E2. IL-I is, therefore, a critical component in the homeostasis of periodontal tissues. ${ }^{6,10}$ These mediators may be responsible for effecting connective tissue destruction, leading to Ioss of attachment. IL-1a, IL 1b, and TNF-a stimulate bone resorption and inhibit bone formation. It synergizes the boneresorptive actions of TNF-alpha, induces the production of matrix metall oproteinase (MMPs), gives rise to an elevated level of procollagenase in both gingival fibroblasts and periodontal ligament (PDL) cells. ${ }^{6}$ No significant change in tissue inhibitors of metalloproteinase (TIMP) synthesis and mRNA was observed after treatment of gingival fibroblasts and PDL cells with IL - I b. In addition, IL-1 stimulates plasminogen activator in gingival fibroblasts, resulting in the generation of plasmin which is a putative, naturally occurring, activator of several matrix metalloproteinase.

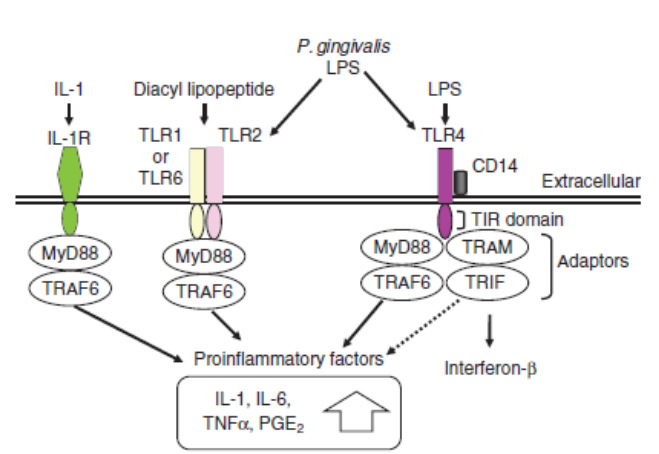

Figure 2: I mmune responses induced by interleukin-1, diacyllipopeptide and lipopolysaccharide induce the production of proinfiammatory factors in the target cells. 
Table1: Classification of Cytokines

\begin{tabular}{|l|l|l|}
\hline Pro-inflammatory cytokines & Anti-inflammatory cytokines & Chemokines \\
\hline IL-1 b, IL-2, IL-6, IL-8, IL-12, IL- 17, IFN-g TNF-a & IL-4, IL-5, IL-10, IL-13, TGF-b & IL-8, MCP-1, MIP-1beta \\
\hline
\end{tabular}

Table2: Interleukins Involved In Acute Inflammation

\begin{tabular}{|c|c|c|c|c|c|c|c|}
\hline IL & Synonyms & Source & Includes & $\begin{array}{l}\text { Genes } \\
\text { Mapped to } \\
\text { Chromosome }\end{array}$ & Structure & cDNA & Function \\
\hline IL-1 & $\begin{array}{l}\text { endogenous } \\
\text { pyrogen (EP), } \\
\text { mononuclear } \\
\text { cell factor, and } \\
\text { lymphocyte } \\
\text { activating factor } \\
\text { (LAF) }\end{array}$ & $\begin{array}{l}\text { Mainly. } \\
\text { Monocytes, } \\
\text { although other } \\
\text { cells may } \\
\text { contribute in } \\
\text { disease states. } \\
\text { Microbial } \\
\text { products such } \\
\text { as LPS or } \\
\text { endotoxin, } \\
\text { potently } \\
\text { upregulate IL-1 } \\
\text { synthesis. }\end{array}$ & $\begin{array}{l}\text { Group of } \\
\text { nine or more } \\
\text { proteins } \\
\text { consisting of } \\
\text { ILIaIL-Ib, IL, } \\
\text { antagonist } \\
\text { (IL-Ira), } \\
\text { IL-18 (also } \\
\text { called IL- } \\
\text { Iy), and the } \\
\text { recently } \\
\text { cloned and } \\
\text { undetermined } \\
\text { ILl8, Il1 E, } \\
\text { ILI£ IL- IH4, } \\
\text { ILT, and IL- } \\
\text { IHI. }\end{array}$ & $\begin{array}{l}\text { Long arm of } \\
\text { chromosome } \\
2, \text { except IL- } \\
18 .^{28}\end{array}$ & & $\begin{array}{l}\text { cDNAs for } \\
\text { IL-la and b } \\
\text { were cloned in } \\
\text { 1984. They are } \\
\text { encoded by two } \\
\text { different genes, } \\
\text { both located } \\
\text { on human } \\
\text { chromosome } \\
\text { 2. Their size } \\
\text { ranges from } \\
22-31 \text { kDa for } \\
\text { cell-associated } \\
\text { molecules, and } \\
17.5 \text { kDa for } \\
\text { the secreted } \\
\text { molecule }\end{array}$ & $\begin{array}{l}\text { Critical for innate } \\
\text { immunity involving } \\
\text { responses to agents. }{ }^{28} \\
\text { Both IL-1a and IL-lb } \\
\text { can trigger fever by } \\
\text { enhancing prostaglandin } \\
\text { E2 (PGE2) synthesis by } \\
\text { various endothelium of } \\
\text { the hypothalamus and } \\
\text { can stimulate T cell } \\
\text { proliferation. IL-1 elicits } \\
\text { the release of histamine } \\
\text { from mast cells at the } \\
\text { site of inflammation } \\
\text { which triggers early } \\
\text { vasodilatation and } \\
\text { increase of vascular } \\
\text { permeability. }{ }^{1}\end{array}$ \\
\hline IL 6 & \begin{tabular}{|l|} 
IFN-b2, \\
hybridoma/ \\
plasmacytoma \\
growth factor, \\
hepatocyte- \\
stimulating \\
factor, \\
B cell stimulatory \\
factor 2 (BSF- \\
2), and B cell \\
differentiation \\
factor (BCDF).
\end{tabular} & $\begin{array}{l}\text { A variety of } \\
\text { cells including } \\
\text { mononuclear } \\
\text { phagocytes, } \\
\text { T cells and } \\
\text { fibroblasts. } \\
\text { Up-regulation } \\
\text { of IL-6 } \\
\text { production has } \\
\text { been observed } \\
\text { in a variety } \\
\text { of chronic } \\
\text { inflammatory } \\
\text { and autoimmune } \\
\text { disorders. }\end{array}$ & & $\begin{array}{l}\text { Chromosome } \\
7 \text { in humans }\end{array}$ & $\begin{array}{l}\text { Glycoprotein } \\
\text { ranging from } \\
21 \text { to } 28 \text { (Da } \\
\text { depending on } \\
\text { the degree } \\
\text { of post- } \\
\text { translational } \\
\text { modification. }\end{array}$ & $\begin{array}{l}\text { cDNA was } \\
\text { cloned in } 1986\end{array}$ & $\begin{array}{l}\text { The stimulation of } \\
\text { acute phase protein } \\
\text { synthesis by the liver, } \\
\text { IL-6 acts as a growth } \\
\text { factor for mature } \\
\text { B cells and induces } \\
\text { their final maturation } \\
\text { into antibody- } \\
\text { producing plasma } \\
\text { cells. It is involved in } \\
\text { T - cell activation and } \\
\text { differentiation, and } \\
\text { participates in the } \\
\text { induction of IL- } 2 \text { and } \\
\text { IL-2 receptor expression. } \\
\text { Some of the regulatory } \\
\text { effects of IL- } 6 \text { involve } \\
\text { inhibition of TNF } \\
\text { production, providing } \\
\text { negative feedback } \\
\text { for limiting the acute } \\
\text { inflammatory response }\end{array}$ \\
\hline IL11 & & $\begin{array}{l}\text { Bone marrow } \\
\text { stromal cells } \\
\text { and by some } \\
\text { fibroblasts }\end{array}$ & & $\begin{array}{l}\text { Located on } \\
\text { the long } \\
\text { arm of } \\
\text { chromosome } \\
19\end{array}$ & $\begin{array}{l}\text { Molecular } \\
\text { weight24 kDa }\end{array}$ & $\begin{array}{l}\text { cDNA was } \\
\text { cloned in } 1990 .\end{array}$ & $\begin{array}{l}\text { A functional homologue } \\
\text { of IL6 and can } \\
\text { replace IL- } 6 \text { for the } \\
\text { proliferation of certain } \\
\text { plasmacytoma cell lines } \\
\text { and in the induction } \\
\text { of acute phase protein } \\
\text { secretion in the } \\
\text { liver. Stimulation of } \\
\text { T cell-dependent B } \\
\text { cell immunoglobulin } \\
\text { secretion, increased } \\
\text { platelet production, } \\
\text { and induction of IL- } 6 \\
\text { expression by T cells. }\end{array}$ \\
\hline
\end{tabular}




\begin{tabular}{|c|c|c|c|c|c|c|c|}
\hline IL-8 & \begin{tabular}{|l|} 
Neutrophil \\
chemotactic \\
factor Neutrophil \\
activating protein \\
(NAP- 1) serves \\
as a prototype \\
for discussing \\
the biologic \\
properties of \\
rapidly growing \\
family of \\
inflammatory \\
mediators
\end{tabular} & $\begin{array}{l}\text { Avariety of } \\
\text { cells including } \\
\text { monocytes, T } \\
\text { lymphocytes, } \\
\text { neutrophils, } \\
\text { vascular } \\
\text { endothelial } \\
\text { cells, dermal } \\
\text { fibroblasts, } \\
\text { keratinocyte, } \\
\text { hepatocytes, and } \\
\text { human gastric } \\
\text { cancer cells. The } \\
\text { production is not } \\
\text { constitutive but } \\
\text { occurs ordinarily } \\
\text { in the presence } \\
\text { of inflammatory } \\
\text { stimuli such as } \\
\text { LPS, IL-1, and } \\
\text { TNF. }\end{array}$ & $\begin{array}{l}\text { belong to a } \\
\text { chemotactic } \\
\text { cytokine } \\
\text { Family } \\
\text { protein. }\end{array}$ & $\begin{array}{l}\text { Chromosome } \\
4 \text { in humans }\end{array}$ & \begin{tabular}{|l|} 
Consists of 72 \\
amino acids \\
in its mature \\
form, is \\
identified as a \\
basic heparin- \\
binding \\
protein
\end{tabular} & $\begin{array}{l}\text { cDNA was } \\
\text { cloned by } \\
\text { three different } \\
\text { laboratories } \\
\text { between } 1987 \\
\text { and } 1989\end{array}$ & $\begin{array}{l}\text { Responsible for the } \\
\text { chemotactic migration } \\
\text { and activation of } \\
\text { neutrophils and } \\
\text { other cell types } \\
\text { (such as monocytes, } \\
\text { lymphocytes, and } \\
\text { eosinophils) at sites of } \\
\text { inflammation. Its main } \\
\text { inflammatory impact } \\
\text { lies in its chemotactic } \\
\text { effects on neutrophils } \\
\text { and its ability to } \\
\text { stimulate granulocyte } \\
\text { activity. enhancing } \\
\text { neutrophil adherence } \\
\text { to endothelial cells } \\
\text { and facilitating their } \\
\text { diapedesis through } \\
\text { vessel walls. }{ }^{1} \text { Thus, } \\
\text { IL-8 mediates } \\
\text { the recruitment } \\
\text { and activation of } \\
\text { neutrophils in inflamed } \\
\text { tissue. }{ }^{29} \\
\end{array}$ \\
\hline $\begin{array}{l}\text { IL- } \\
16^{1}\end{array}$ & $\begin{array}{l}\text { originally } \\
\text { identified as } \\
\text { a chemotactic } \\
\text { factor known } \\
\text { as lymphocyte } \\
\text { chemoattractant } \\
\text { factor or } \\
\text { lymphotactin. }\end{array}$ & $\begin{array}{l}\text { unusual } \\
\text { cytokine- } \\
\text { preformed } \\
\text { IL-16 is stored } \\
\text { in CD8+ } \\
\text { lymphocyteand } \\
\text { is secreted upon } \\
\text { stimulation } \\
\text { with histamine / } \\
\text { serotonin. }\end{array}$ & $\begin{array}{l}\text { The only } \\
\text { member } \\
\text { of the "C" } \\
\text { family of } \\
\text { chemokines. }\end{array}$ & $\begin{array}{l}\text { human } \\
\text { chromosome } \\
1 .\end{array}$ & & & $\begin{array}{l}\text { Induces chemotaxis of } \\
\text { CD4+ T lymphocytes } \\
\text { and is believed to } \\
\text { initiate T-cell mediated } \\
\text { inflammation in asthma. }{ }^{1}\end{array}$ \\
\hline IL17 & & $\begin{array}{l}\text { is a product } \\
\text { of activated T } \\
\text { lymphocytes }\end{array}$ & & & & $\begin{array}{l}\text { human IL-17 } \\
\text { cDNA was } \\
\text { cloned in } \\
1995 \text { based on } \\
\text { homology with } \\
\text { murine CTLA8 } \\
1.9 \text { Kb cDNA } \\
\text { was found to } \\
\text { encode a protein } \\
\text { of } 17.5 \text { kDa } \\
\text { homologous to } \\
\text { a product of } \\
\text { Herpes virus } \\
\text { saimiri (HVS13). }\end{array}$ & $\begin{array}{l}\text { Stimulation of IL-6 } \\
\text { and IL-8 production } \\
\text { and enhanced ICAM1 } \\
\text { expression on human } \\
\text { foreskin fibroblasts. }{ }^{1}\end{array}$ \\
\hline
\end{tabular}

Table3.The cytokines known to mediate chronic inflammatory processes can be divided into ${ }^{1}$

\begin{tabular}{|l|l|}
\hline Participating in humoral inflammation & Contributing to cellular inflammation \\
\hline $\begin{array}{l}\text { IL-3, IL-4, IL-5, IL-6, IL-7, IL-9, IL-10, IL-13, and transforming } \\
\text { growth factor-b (TGF-b) }\end{array}$ & $\begin{array}{l}\text { as IL-1,IL-2,IL-3, IL-4, IL-7, IL-9, IL-10, IL-12, interferons (IFNs), } \\
\text { IFN-g inducing factor GF-b, and TNF-a and -b. }\end{array}$ \\
\hline
\end{tabular}


Table 4: Interleukin Involved In Chronic Inflammation

\begin{tabular}{|c|c|c|c|c|c|c|}
\hline IL & Other Name & Source & $\begin{array}{l}\text { Genes mapped } \\
\text { to chromosome }\end{array}$ & Structure & $\mathrm{cDNA}$ & Function \\
\hline IL2 & $\begin{array}{l}\text { Originally } \\
\text { known as T cell } \\
\text { growth factor } \\
\text { (TCGF). }\end{array}$ & $\begin{array}{l}\text { Mainly by } \\
\text { activated T } \\
\text { helper cells. }\end{array}$ & $\begin{array}{l}\text { Long arm of } \\
\text { chromosome } 4 .\end{array}$ & $\begin{array}{l}15 \mathrm{kDa} \\
\text { glycoprotein }\end{array}$ & $\begin{array}{l}\text { The human } \\
\text { IL-2 cDNA was } \\
\text { cloned in } 1983\end{array}$ & $\begin{array}{l}\text { Acts as a growth factor/activator } \\
\text { for T cells, NK cells, and B cells } \\
\text { and promotes the development } \\
\text { of lymphokine-activated killer } \\
\text { (LAK) cells. It therefore plays a } \\
\text { critical role in regulating both } \\
\text { cellular and humoral chronic } \\
\text { inflammatory responses. Binding } \\
\text { of IL-2 to the IL-2 receptor on } \\
\text { T lymphocytes leads to cell } \\
\text { proliferation, increased lymphokine } \\
\text { secretion(IFNg,lymphotoxin,IL-4, } \\
\text { IL-3, IL-5, GM-CSF), and enhanced } \\
\text { expression of class II MHC } \\
\text { molecules. }\end{array}$ \\
\hline IL3 & multi-CSF & $\begin{array}{l}\text { activated T } \\
\text { cells and mast } \\
\text { cells }\end{array}$ & $\begin{array}{l}\text { localized to } \\
\text { chromosome } 5\end{array}$ & $\begin{array}{l}\text { The molecular } \\
\text { weight of IL-3 } \\
\text { ranges from } \\
14 \text { to } 36 \mathrm{kDa}\end{array}$ & $\begin{array}{l}\text { The cloning } \\
\text { of the } \\
\text { corresponding } \\
\text { Cdna was } \\
\text { reported in } 1984\end{array}$ & $\begin{array}{l}\text {-Stimulates eosinophils and B cell } \\
\text { differentiation } \\
\text {-Inhibits lymphokine activated killer } \\
\text { (LAK) cell activity. } \\
\text {-IL-3 shares activities with GM- } \\
\text { CSF,not only stimulates the effectors } \\
\text { Ieucocytes, but can also regulate their } \\
\text { localization to inflammatory sites by } \\
\text { the acting on endothelium. } \\
\text {-The ability of IL-3 to enhance MHC } \\
\text { class II expression is not limited } \\
\text { to monocytes, eosinophils and } \\
\text { neutrophils but also encompasses } \\
\text { endothelial cells. } \\
\text {-stimulates secretion of the } \\
\text { circulating cytokines IL-6 and G-CSF } \\
\text { by the vascular endothelium suggests } \\
\text { an alternative, indirect mechanism } \\
\text { by which IL-3 could influence } \\
\text { haemopoiesis in the bone marrow. }{ }^{23}\end{array}$ \\
\hline IL4 & & $\begin{array}{l}\text { CD4+ } \\
\text { Thcells, mast } \\
\text { cells, } \\
\text { basophils. }\end{array}$ & $\begin{array}{l}\text { Human } \\
\text { chromosome5 }\end{array}$ & $\begin{array}{l}\text { Expressed as } \\
\text { a } 15-19 \mathrm{kDa} \\
\text { protein and } \\
\text { exists as a } \\
\text { dimer }\end{array}$ & $\begin{array}{l}\text { cDNA was } \\
\text { cloned in } 1986 .\end{array}$ & $\begin{array}{l}\text { It induces CD4+ T cells to } \\
\text { differentiate into TH2 cells while } \\
\text { suppressing the development of Th1 } \\
\text { cells. } \\
\text { It also acts as a B cell, T cell, and } \\
\text { mast cell growth factor, it enhances } \\
\text { class II MHC expression on B cells, } \\
\text { and it promotes immunoglobulin class } \\
\text { switching to IgG } 1 \text { and IgE. In fact, } \\
\text { IL-4 is necessary for IgE response } \\
\text { induction, and its absence also leads } \\
\text { to significantly lower levels of IgG1 in } \\
\text { T cell-dependent immune responses. } \\
\text { The stimulatory effect of IL-4 on IgG1 } \\
\text { and IgE production and on MHC class } \\
\text { II induction are down-regulated by } \\
\text { IFN-g, a cytokine whose functions are } \\
\text { antagonized by IL-4 and vice versa. } \\
\text { IL-4 also stimulates collagen and } \\
\text { IL-6 production by human dermal } \\
\text { fibroblasts, and may thus play a } \\
\text { role in the pathogenesis of fibrotic } \\
\text { diseases such as systemic sclerosis. }\end{array}$ \\
\hline
\end{tabular}




\begin{tabular}{|c|c|c|c|c|c|c|}
\hline IL5 & $\begin{array}{l}\text { as B cell } \\
\text { growth factor II } \\
\text { (BCGFII) and } \\
\text { T cell replacing } \\
\text { factor (TRF) }\end{array}$ & $\begin{array}{l}\text { produced by } \\
\text { CD4+ T helper } \\
\text { cells well as } \\
\text { NK cells }\end{array}$ & $\begin{array}{l}\text { chromosome } 5 \\
\text { in humans. }\end{array}$ & $\begin{array}{l}\text { a protein of } \\
20-22 \mathrm{kDa} \\
\text { which has } \\
\text { an apparent } \\
\text { molecular } \\
\text { weight of } 45 \\
\text { kDa upon } \\
\text { dimerization. } \\
\text { Exists as a } \\
\text { dimer linked } \\
\text { by disulfide } \\
\text { bonds. }\end{array}$ & is cloned in 1987 & $\begin{array}{l}\text { Involved in eosinophil differentiation } \\
\text { and activation and stimulation of } \\
\text { immunoglobulin class switching } \\
\text { to IgA. It also includes increased } \\
\text { activation of B cell proliferation and } \\
\text { enhancement of T cell cytotoxicity. } \\
\text { The combined production of IL- } 4 \text { and } \\
\text { IL-5 by CD4+ TH } 2 \text { cells. Therefore, } \\
\text { results in IgE and IgA production and } \\
\text { mast cell and eosinophil stimulation. }{ }^{1}\end{array}$ \\
\hline IL-7 ${ }^{30}$ & & $\begin{array}{l}\text { IL-7, a } \\
\text { cytokine } \\
\text { purified as } \\
\text { a pre-B cell } \\
\text { growth factor, } \\
\text { is a bone } \\
\text { marrow and } \\
\text { thymic stromal } \\
\text { cell product }\end{array}$ & $\begin{array}{l}\text { Human } \\
\text { chromosome } 8\end{array}$ & $25 \mathrm{kDa}$ & $\begin{array}{l}\text { cDNA was } \\
\text { cloned in } 1989 .\end{array}$ & $\begin{array}{l}\text { It stimulates the development of } \\
\text { pre-B and pre-T cells and acts as a } \\
\text { growth factor for B cells, T cells, and } \\
\text { early lymphocytes. }\end{array}$ \\
\hline IL $9^{31}$ & $\begin{array}{l}\text { Was known } \\
\text { as mast } \\
\text { cell growth- } \\
\text { enhancing } \\
\text { activity (MEA) } \\
\text { and murine } \\
\text { T-cell growth } \\
\text { factor P40 }\end{array}$ & $\begin{array}{l}\text { CD4 T helper } \\
\text { (TH2) cells as } \\
\text { well as some B } \\
\text { lymphomas. } \\
\text { Its production } \\
\text { is IL-4 and } \\
\text { IL-10, and } \\
\text { thus IL-2- } \\
\text { dependent }\end{array}$ & $\begin{array}{l}\text { human } \\
\text { chromosome } 5\end{array}$ & & $\begin{array}{l}\text { cDNA was } \\
\text { cloned in } 1989\end{array}$ & $\begin{array}{l}\text { Involved in early hematopoietic } \\
\text { ontogeny, can influence pro } \\
\text { inflammatory cytokines such as } \\
\text { TNF, ILI, INF and also affect } \\
\text { differentiation and functioning of } \\
\text { both Th17 and Treg cells. } \\
\text { IL9- mediated signaling responses } \\
\text { have been dependent on the Janus } \\
\text { kinase (JAK-1)-signal transducer and } \\
\text { activator of transcription pathways. } \\
\text { 15is regulatory in nature in that it } \\
\text { inhibits lymphokine production by } \\
\text { IFN-g-producing CD4+ T cells and } \\
\text { enhances the growth of CD8+ T } \\
\text { cells. In addition, IL-9 promotes the } \\
\text { production of immunoglobulins by } \\
\text { B cells and the proliferation of mast } \\
\text { cells. }\end{array}$ \\
\hline IL $10^{1}$ & $\begin{array}{l}\text { B cell-derived } \\
\text { T cell growth } \\
\text { factor Cytokine } \\
\text { synthesis } \\
\text { inhibitory } \\
\text { factor (CSIF) } \\
\text { because it } \\
\text { inhibits IFN1-g } \\
\text { production by } \\
\text { activated T } \\
\text { cells. } \\
\text { IL-10 is } \\
\text { considered a } \\
\text { T cell cross- } \\
\text { regulatory } \\
\text { factor and } \\
\text { has thus been } \\
\text { referred to as an } \\
\text { "anticytokine". }\end{array}$ & $\begin{array}{l}\text { Produced by } \\
\text { a variety of } \\
\text { cell types, } \\
\text { Including } \\
\text { CD4+ T cells, } \\
\text { activated } \\
\text { CD8+ T cells, } \\
\text { and activated } \\
\text { B cells }\end{array}$ & & 18kDa protein & $\begin{array}{l}\text { The cDNA for } \\
\text { human IL-10 } \\
\text { was cloned in } \\
1990\end{array}$ & $\begin{array}{l}\text {-Reduction of antigen-specific T } \\
\text { cell proliferation, Inhibition of IL- } \\
2 \text {-induced IFN-g production by NK } \\
\text { cells, and inhibition of IL-4 and IFN-g } \\
\text { induced MHC class II expression } \\
\text { on monocytes. Since IL-10 can be } \\
\text { produced by TH2 cells and inhibits } \\
\text { TH1 function by preventing TH1 } \\
\text { cytokine production (such as IFN-g } \\
\text { IL-10 also acts as a co-differentiation } \\
\text { factor for cytotoxic T cells and a co- } \\
\text { factor for T cell growth. } \\
\text { Human IL-10 (hIL-10) shares } 84 \% \\
\text { identity at the amino acid level with } \\
\text { a homolog, viral IL-10 (vIL-10), which } \\
\text { is encoded by the Epstein-Barr virus. } \\
\text { vIL- } 10 \text { shares will hiLe10 inhibitory } \\
\text { effects on cytokine production and } \\
\text { stimulatory effects on B cell growth. }\end{array}$ \\
\hline
\end{tabular}




\begin{tabular}{|c|c|c|c|c|c|c|}
\hline IL13 & $\begin{array}{l}\text { Originally } \\
\text { identified } \\
\text { as a protein } \\
\text { produced by } \\
\text { activated } \\
\text { murine Th2 } \\
\text { lymphocytes } \\
\text { and referred to } \\
\text { as P600 (K D. } \\
\text { Brown 1989). }\end{array}$ & & $\begin{array}{l}\text { Human } \\
\text { chromosome5, } \\
\text { closely linked } \\
\text { to the gene } \\
\text { encoding IL-4 }\end{array}$ & $\begin{array}{l}12-17 \mathrm{kDa} \\
\text { protein }\end{array}$ & $\begin{array}{l}\text { The cDNA for } \\
\text { IL- } 13 \text { was } \\
\text { recently cloned }\end{array}$ & $\begin{array}{l}\text { IL-13 exhibits anti-inflammatory } \\
\text { activities by inhibiting the production } \\
\text { of inflammatory cytokines, such as } \\
\text { IL-lb, TNF-a, IL- 8, and IL-6, by } \\
\text { human peripheral blood monocytes } \\
\text { induced with LPS. } \\
\text { Inhibition of inflammatory cytokine } \\
\text { production is also a characteristic of } \\
\text { two other cytokines produced by TH2 } \\
\text { lymphocytes, namely IL-4 and IL-10. } \\
\text { In addition, IL-13 enhances monocyte } \\
\text { and B lymphocyte differentiation } \\
\text { and proliferation, increases CD23 } \\
\text { expression, and induces IgG4 and IgE } \\
\text { class switching. }{ }^{1}\end{array}$ \\
\hline IL14 ${ }^{1}$ & & $\begin{array}{l}\text { A product of } \\
\text { malignant B } \\
\text { and T cells as } \\
\text { well as normal } \\
\text { T cells. }\end{array}$ & & $\begin{array}{l}53 \mathrm{kDa} \text { growth } \\
\text { factor (BCGF) }\end{array}$ & & $\begin{array}{l}\text { Induce B cell proliferation. However, } \\
\text { IL-14 inhibits immunoglobulin } \\
\text { secretion. } \\
\text { It has been suggested to play an } \\
\text { important role in the aggressive } \\
\text { form of B-cell type non-Hodgkin's } \\
\text { lymphoma. }{ }^{1}\end{array}$ \\
\hline IL 12 & $\begin{array}{l}\text { Natural killer } \\
\text { cell stimulatory } \\
\text { factor (NKSF) } \\
\text { and cytotoxic } \\
\text { lymphocyte } \\
\text { maturation } \\
\text { factor (CLMF), }\end{array}$ & $\begin{array}{l}\text { originally } \\
\text { isolated from } \\
\text { Epstein- } \\
\text { Barr virus } \\
\text { transformed B } \\
\text { cells. } \\
\text { secreted by } \\
\text { activated } \\
\text { B cells, } \\
\text { macrophages, } \\
\text { and other } \\
\text { antigen } \\
\text { presenting } \\
\text { cells (APCs) } \\
\text { but its } \\
\text { production is } \\
\text { inhibited by } \\
\text { IL-4 and IL-10 }\end{array}$ & & $\begin{array}{l}\text { It is a } \\
\text { heterodimer } \\
\text { composed of } \\
\text { two subunits } \\
\text { of } 35 \text { and } 40 \\
\mathrm{kDa} \text {. }\end{array}$ & $\begin{array}{l}\text { cDNAs for both } \\
\text { subunits were } \\
\text { cloned in } 1991\end{array}$ & $\begin{array}{l}\text { The biological activities include } \\
\text { enhancement of cytotoxic T cells } \\
\text { and lymphokine activated 'killer } \\
\text { (LAK) cell generation and activation, } \\
\text { increased natural killer (NK) cell } \\
\text { cytotoxicity, induction of activated } \\
\text { T cell and NK cell proliferation, } \\
\text { induction of 1FN-g production by } \\
\text { NK cells and T cells, and inhibition } \\
\text { of IgE synthesis by IL-4-stimulated } \\
\text { lymphocytes via IFN-g-dependent } \\
\text { and independent mechanisms. } \\
\text { In addition, the stimulatory effect } \\
\text { of IL-12 on Th1 development is } \\
\text { antagonized by IL-4, a cytokine which } \\
\text { promotes Th2 cell development. } \\
\text { Therefore, IL-12 plays an important } \\
\text { role in cell-mediated inflammation } \\
\text { and also contributes to the regulation } \\
\text { of } \\
\text { immunoglobulin production. }{ }^{1}\end{array}$ \\
\hline $\mathrm{IL} 5^{1}$ & $\begin{array}{l}\text { Originally } \\
\text { discovered } \\
\text { as a T cell } \\
\text { stimulatory } \\
\text { activity }\end{array}$ & $\begin{array}{l}\text { produced by } \\
\text { activated } \\
\text { monocyte, } \\
\text { epithelial cells, } \\
\text { and fibroblasts }\end{array}$ & Chromosome4 & $\begin{array}{l}\text { Approximately } \\
15 \mathrm{kDa} \\
\text { IL-15 does } \\
\text { not exhibit } \\
\text { any sequence } \\
\text { homology with } \\
\text { IL-2 }\end{array}$ & & $\begin{array}{l}\text { Shares many biologic properties with } \\
\text { IL-2 and mediates its activity via a } \\
\text { multi-subunit high affinity receptor } \\
\text { comprised of a unique alpha chain } \\
\text { and the beta and gamma chains of } \\
\text { the IL-2R. } \\
\text { It stimulates T lymphocyte and NK } \\
\text { cell proliferation, as well as CTL } \\
\text { and LAK activity. It enhances B } \\
\text { cell expansion and immunoglobulin } \\
\text { production. It is also a T lymphocyte } \\
\text { chemoattractant. IL-15 may be } \\
\text { responsible for the recruitment } \\
\text { and activation of T lymphocytes } \\
\text { in the synovium of patients with } \\
\text { rheumatoid arthritis where its levels } \\
\text { have been found to be elevated. }\end{array}$ \\
\hline
\end{tabular}




\section{Table 5: Review of Literature}

\begin{tabular}{|c|c|c|}
\hline AUTHORS AND YEAR & STUDY & RESULTS \\
\hline $\begin{array}{l}\text { 1. Carol A. Feghali et al } \\
1997^{1}\end{array}$ & Review & $\begin{array}{l}\text { This review describes the role of cytokines those involved in acute inflammation and } \\
\text { those responsible for chronic inflammation and also summarizes features of the cell- } \\
\text { surface receptors that mediate the inflammatory effects of the described cytokines. }\end{array}$ \\
\hline $\begin{array}{l}\text { 2. H. Okada and S.Murakami } \\
1998^{2} \text {. }\end{array}$ & Review & $\begin{array}{l}\text { In this review, summarized the information regarding cytokine expression in the } \\
\text { periodontium and its possible relationship with tissue homeostasis and inflammatory } \\
\text { disease progression. }\end{array}$ \\
\hline Bosshardt DD et al $2005^{3}$ & Review & - \\
\hline 4. $\quad$ Yen-chung.Et al $2010^{6}$ & Review & $\begin{array}{l}\text { Its summary of the overall contributions and balance of cytokines during periodontal } \\
\text { infection. }\end{array}$ \\
\hline Bartold PM et al $2000^{7}$ & Review & Describe the interleukins according to Molecular and cell biology of the gingiva. \\
\hline J.A.bochla et al $2008^{28}$ & Review & Interleukin 1 Signal Transduction in Periodontitis \\
\hline Baggiolini et al $2008^{32}$ & Review & This review describe about Chemokines in pathology and medicine \\
\hline $\begin{array}{l}\text { 8. } \\
\text { Akihisa Harada et al } 1998\end{array}$ & Review & $\begin{array}{l}\text { IL- } 8 \text { plays a causative role in acute inflammation by recruiting and activating } \\
\text { neutrophils }\end{array}$ \\
\hline $\begin{array}{l}\text { 9. } \\
2003^{23}\end{array}$ & Review & $\begin{array}{l}\text { IL-3 was found to regulate endothelial responses related to inflammation, immunity } \\
\text { and haemopoiesis. These findings, summarized in this review, offer new insight into } \\
\text { the physiological function of IL-3 and may also be of clinical importance, as IL-3 is } \\
\text { used in bone marrow reconstitution following cancer therapy. }\end{array}$ \\
\hline 10. D.T. Grave,D.Cochrane ${ }^{34}$ & Review & The contribution of IL-1 and TNF to periodontal destruction \\
\hline 11. JohnJ.Taylor $2010^{10}$ & Review & Cytokine regulation of immune responses to Porphyromonasgingivalis. \\
\hline 12. Masanori Koide et al 2010 & Review & $\begin{array}{l}\text { In this review, summarize the mechanism by which osteoblasts and bone marrow } \\
\text { stromal cells regulate osteoclast differentiation and function, and the bacterial } \\
\text { strategy for bone resorption in periodontitis and further describe possible therapeutic } \\
\text { approaches that may be used to prevent alveolar bone loss in periodontitis. }\end{array}$ \\
\hline $\begin{array}{l}\text { 13. K.V.Arun, Avaneendra } \\
\text { Talwar, T.S.S.Kumar } 2011 \\
35\end{array}$ & Review & $\begin{array}{l}\text { This review focuses on the subsets, including the recently identified cells of the CD4 } \\
\text { lineage, their activation pathways and effectors function in periodontal disease. } \\
\text { The roles of Th } 17 \text { and regulatory T (Treg) Cells in disease pathogenesis have been } \\
\text { explored. Newer Th subsets such as Th9 and Th22 cells and their potential role in } \\
\text { periodontal disease have also been outlined. }\end{array}$ \\
\hline $\begin{array}{l}\text { Gemmell E, Yamazaki k, } \\
\text { Seymour GJ. } 2007^{36}\end{array}$ & Review & $\begin{array}{l}\text { This review focuses on the role of } \mathrm{T} \text { cells in periodontal disease, homeostasis and } \\
\text { autoimmunity. }\end{array}$ \\
\hline $\begin{array}{l}\text { 15. Gemmell E, Yamazaki K, } \\
\text { Seymour GJ } 2002^{37}\end{array}$ & Review & $\begin{array}{l}\text { The roles of interleukin (IL)-1,prostaglandin (PGE 2) and metalloproteinases as the } \\
\text { destructive mediators in periodontal disease were largely understood, the control } \\
\text { and regulation of these cytokines remained controversial. Two apparently conflicting } \\
\text { theories have emerged. One is based on direct observations of human lesions, while } \\
\text { the other is based on animal model experiments and the inability to demonstrate } \\
\text { IL } 4 \text { mrna in gingival extracts. As part of the "Controversy" series, this review is } \\
\text { intended to stimulate debate and hence may appear in some places provocative. }\end{array}$ \\
\hline 16. Palmqvist $\mathrm{P}$ et al $2008^{8}$ & $\begin{array}{l}\text { In vitro Cell } \\
\text { culture }\end{array}$ & IL-b and TNF-a regulate IL- 6 type cytokines in gingival fibroblasts. \\
\hline 17. $\quad$ R.G.Goodwin et al $1989^{30}$ & $\begin{array}{l}\text { In vitro Cell } \\
\text { culture }\end{array}$ & $\begin{array}{l}\text { Human interleukin } 7 \text { regulate the molecular cloning and growth factor activity on } \\
\text { human and murine B-lineage cells. }\end{array}$ \\
\hline 18. F.Q. Cunha et al $1999^{38}$ & $\begin{array}{l}\text { In Vitro Cell } \\
\text { culture }\end{array}$ & $\begin{array}{l}\text { The effect of IL- } 4 \text { on responses to intraplantar (i.pl.) Carrageenin , bradykinin, tnfa, } \\
\text { IL-1b, IL- } 8 \text { and PGE2 was investigated in a model of mechanical hyperalgesia in } \\
\text { rats. Also, the celluar source of the IL- } 4 \text { was investigated. And data suggest that } \\
\text { IL- } 4 \text { released by mast cells limits in amatory hyperalgesia. During the early phase } \\
\text { of the in ammatory response the mode of action of the IL } 4 \text { appears to be inhibition } \\
\text { of the production tnfa, IL-1b and IL- } 8 \text {. In the later phase of the response, in addition } \\
\text { to inhibiting the production of pro-in ammatory cytokines, IL } 4 \text { also may inhibit the } \\
\text { release of pgs. }\end{array}$ \\
\hline 19. SudhaAgarwal et al $1985^{34}$ & $\begin{array}{l}\text { In Vitro Cell } \\
\text { culture }\end{array}$ & $\begin{array}{l}\text { Functional Role of Interleukin } 1 \text { in Periodontal Disease; Induction of Interleukin } 1 \\
\text { Production by Bacteroidesgingivalis Lipopolysaccharide in Peritoneal Macrophages } \\
\text { from C3H/hen and C3H/hej Mice }\end{array}$ \\
\hline $\begin{array}{l}\text { 20. Fujita T, Ashikaga A, et al } \\
2008^{39}\end{array}$ & In vitro & $\begin{array}{l}\text { Irsogladine maleate counters the interleukin- } 1 \text { b- induced suppression in gap- } \\
\text { junctional intercellular communication but does not affect the interleukin-1b- } \\
\text { induced zonulaoccludens protein- } 1 \text { levels in human gingival epithelial cells. }\end{array}$ \\
\hline
\end{tabular}




\begin{tabular}{|ll|l|l|}
\hline 21. & SudhaAgarwal $1998^{40}$ & In vitro & $\begin{array}{l}\text { Induction of Interleukin 1 Production by Bacteroidesgingivalis Lipopolysaccharide } \\
\text { in Peritoneal Macrophages from C3H/hen and C3H/hej Mice }\end{array}$ \\
\hline 22. $\quad$ Hosokawa Y $2009{ }^{41}$ & In vitro & $\begin{array}{l}\text { Cytokines differentially regulate CXCL 10 production by interferon-c-stimulated or } \\
\text { tumor necrosis factor-a stimulated human gingival fibroblasts. }\end{array}$ \\
\hline 23. $\quad$ Steinberg T et al $2006^{42}$ & In vitro & $\begin{array}{l}\text { Analysis of interleukin-1b-modulated mrna gene transcription in human gingival } \\
\text { keratinocytes by epithelia -specific cdna microarrays. }\end{array}$ \\
\hline 24. $\quad$ Sung Woo Lee et al $2002^{43}$ & In vitro & $\begin{array}{l}\text { Anti-inflammatory effects of IL-4 and IL-10 on Human Polymorphonuclear } \\
\text { Leukocytes. }\end{array}$ \\
\hline 25. $\quad$ Rawlinson A, $2003^{44}$ & In vivo & $\begin{array}{l}\text { Interleukin 1 and receptor antagonist levels in gingival crevicular fluid in heavy } \\
\text { smokers versus non -smokers. }\end{array}$ \\
\hline 26. $\quad$ Lester SR, $2009^{45}$ & In vivo & $\begin{array}{l}\text { Relationship between the gingival sulcus depth and interleukin -1 insoform } \\
\text { concentrations within the adjacent gingival tissue. }\end{array}$ \\
\hline 27. $\quad$ Kaushik R et al $2011^{46}$ & In vivo & $\begin{array}{l}\text { Interleukin-1 Beta Levels in } \\
\text { Chronic Periodontitis Patients } \\
\text { Before and After Periodontal } \\
\text { Phase I Therapy and Healthy } \\
\text { Controls-A Case- Control Study }\end{array}$ \\
\hline
\end{tabular}

Interleukin-1, diacyllipopeptide and lipopolysaccharide are recognized by interleukin-1 receptor (IL- $1 \mathrm{R}$ ), a complex of TLR2 and TLR6, and TLR4, respectively. CD14 is a membraneanchored glycoprotein that aids the binding of lipopolysaccharide and TLR4. IL-1R and the TLRs possess a common TIR domain. Through their TIR domains, IL-1R and the TLRs activate MyD88 as a common signaling molecule. TRAF 6 is a signaling molecule downstream of MyD88. Thus, interleukin1 and diacyllipopeptideactivate the MyD8S / TRAF 6 pathway to induce biological responses. In contrast, TLR4 has two signaling pathways: the MyD88 / TRAF 6 pathway and the TRAM / TRIF pathway. The TRAM / TRIF pathway plays an essential role in interfer on-b production. In macrophages, both the MyD88/TRAF 6 and TRAM TRIF pathways are required for lipopolysaccharide-induced biological actions such as interleukin-6 production. Lipopolysaccharide isolated from $P$. gingivalis was shown to use both TLR4 and a complex of TLR2 plus TLR1 or TLR6 to induce biological responses, PGE2, prostaglandin E2; IL, interleukin; LPS, lipopolysaccharide; MR. Toil-like receptor; TNFa, tumor necrosis factor a; TRAF 6, TNF receptor associated factor 6 MyD88, myeloid differentiation factor 88; TIR domain, Toll I IL-1R domain; TRW, TIR domain-containing adaptor-inducing interferonb; TRAM, TRIF-related adaptor molecule $\mathrm{e}^{11 .}$

IL 12 is regarded as a pro-inflammatory cytokine with immunoregulatory function, it may be greatly involved in chronic periodontitis.IL-12 acts not only as an activator of macrophages in the inflammed tissue, increasing their phagocytic and bacteriocidal activity, but also increases the ability of macrophages to produce IL 12 in a powerful positive feedback loop. It acts as both as an inflammatory mediator and also initiate host immune response within the periodontal tissues. ${ }^{6} \mathrm{t}$ was al so suggested that I L- 6 may act as an autocrine and/or paracrine factor in bone resorption in pathologic states by stimulating the formation of osteoclasts and the activation of osteoclastic bone resor ption. ${ }^{11}$ L ocally secreted I L-8 induces neutrophil extravasation at the site of inflammation and that the numerous neutrophils present in the Iamina propria and the epithelium of inflamed gingiva may be directed there by IL-8. ${ }^{11}$

\section{Interleukins in Connective Tissue Destruction}

An early event in pathogenesis of periodontal disease is dissolution of approximately $70 \%$ of gingival connectivetissue. Collagen breakdown may occur by two pathways (intracellular and extracellular). I LI inhibit the intracellular pathway while stimulating extracellular route, induces the production of MMPs and elevated level of procollagenase in both gingival fibroblasts and periodontal ligament, stimulates the plasminogen activator in gingival fibroblast resulting in generation of plasmin which is naturally occurring activator for MMP .

\section{Interleukins in Bone Destruction}

Hausmann speculated that periodontal bone loss was multifactorial, "involving a series of interactions between agent in plaque and mediators in periodontal tissue. ${ }^{12}$ Once "critical level of proinflammatory cytokine production is reached, a physiologic response become pathologic. If the 
infiammation occurs predominantly in the cementum, it will result in loss of attachment.If occurs near alveolar bone, bone loss occurs. If the inflammatory front does not progress far from the epithelium, the resulting lesion restricted to gingivitis.

PMN's and monocyte of innate immune response produce ILI and TNF a that produces bone resorption. IL 6 causes bone resorption in pathological state by stimulating the formation of osteoclast and activation of osteoclastic resorption. $1 \mathrm{~L} 8$ is potent chemotatic for leukocyte and induces extravasation of neutrophils at the site of inflammation. These neutrophils contribute to local tissue destruction and bone resorption of periodontal tissue. $1 \mathrm{~L} 17$ which shown to stimulate endothelial cell, fibroblastic cell to produce IL6, IL 8 and PGE2 which are good activator for RANKL production by osteoblast and thus influence on osteoclastic bone resorption.

\section{Interleukins in Chronic Periodontitis}

Chronic periodontitis is an inflammatory response in the periodontal tissues. Chronic periodontitis in adults typically follows a cyclical course, with some forms remaining stable over many years and other forms progressing with subsequent tooth loss despite extensive treatment. ${ }^{13}$ The initial immune response in chronic periodontitis occurs following colonization of the gingival sulcus by periodontopathic bacteria. The presence of the bacteria induces the production of cytokines and chemokines by the gingival epithelium. This results in the expression of adhesion molecules, increased permeability of gingival capillaries and chemotaxis of polymorphonuclear neutrophils through the junctional epithelium and into the gingival sulcus. The specific cytokines and chemokines produced by this initial response lead to a perivascular T-cell / macrophage dominated inflammatory infiltrate in the connective tissues. If this cell-mediated immune response does not control the bacterial challenge, progression to a B-cell /plasma-cell lesion occurs. The antibodies subsequently produced may be protective and control the infection, or may be non-protective with resultant connective tissue destruction and bone loss. ${ }^{14}$ The early / stable lesion of chronic periodontitis is dominated by macrophages and Tcells, suggesting that Th1 cytokines are important in the development of this response, while the advanced/progressivelesion of chronic periodontitis, which is characterized by B-cells and plasma cells, is dependent upon Th2 cytokines. ${ }^{15} \mathrm{Thl}$ cytokines include interleukin-2 and interferon-gamma and promote cell-mediated immunity, while the Th2 cytokine, interleukin-4, suppresses cell-mediated responses and enhances humoral immunity. A reduced Th I response has been shown in chronic periodontitis, where peripheral blood mononuclear cells obtained from patients with chronic periodontitis and then stimulated with mitogens, Porphyromonas gingivalis and Fusobacteriumnucleatum showed lower levels of Th1 cytokines(IL2,interferon gamma).Additionally, increased levels of Th2 cytokines (IL-4, IL-5, IL-6, IL-9, IL-10, and IL- 13) have been reported in GCF, gingival tissue ${ }^{15}$ and peripheral blood of patients with chronic periodontitis. ${ }^{16}$

The role of interleukin-10 in human chronic infections is both complex and critical. It has been implicated in the pathogenesis of chronic periodontitis, is critical in controlling the balance between Thl cells and Th2 cells in chronic periodontitis, whereby an excess of interleukin-10 may shift the balance in favor of a Th2 response and progressive disease, whereas its shortage leads to increased interleukin-1 production and increased tissue destruction. ${ }^{17}$ By contrast, high levels of IL 10 may even inhibit B-cell activation and proliferation, hence further illustrating its complex role. Low levels of I L-10 have been demonstrated in chronic periodontitis lesions compared with gingivitis, which may allow continued polyclonal Bcell activation to occur. ${ }^{18}$

Th17 cells are characterized by the production of interleukin-17. Th17 cell development depend upon the presence of interleukin-23 (a monocyte product) and also IL 6 and TGF-b. Interleukin-17 expression is higher in chronic periodontitis tissues than in healthy tissues, along with I L-1b andTNF a. ${ }^{19}$ It induces the production of pro-MMP-1 and MMP-3 by gingival fibroblasts. In contrast, interleukin-17 receptor knockout mice showed increased $P$. gingivalis-induced periodontal bone loss, suggesting its possible protective role ingingivalis-induced tissue destruction. ${ }^{20-22 .}$

IL- 1 levels were elevated in GCF at periodontitis sites and that marked reductions of total IL- 1 levels were observed following effective treatment. They also commented that IL-b was detected more frequently than IL-lex in GCF from untreated patients with periodontitis. ${ }^{21}$

\section{Interleukins in Refractory Periodontitis}

Reinhardt and colleagues (1993) reported that 
el evated levels of I L 1a, I L-13, and I L-6 were detected in the GCF of patients with refractory periodontitis. A possiblecorrelation among bleeding index, probing depth, and the I L-6 levels of the crevicular fluid has also been demonstrated. ${ }^{21}$

\section{Interleukins in Aggressive Periodontitis}

B-cell/plasma-cell nature of the aggressive periodontitis lesion makes it likely obe Th2mediated lesion. It has been shown that Th17 cells can be converted to Thl cells or Th2 cells under the influence of interleukin-12 or interleukm-4 respectively, while CD4+, CD25+,forkhead box P3 (Foxp3+) regulatory $\mathrm{T}$-cells can be converted to an interleukin-17-producing cell when co-cultured with dendritic cells selectively activated via dectin-1. These latter findings highlight the complex regulatory networks that are probably operating in both chronic and aggressive peniodontitis. ${ }^{23}$

IL-8 is a chemoattractant for neutrophils expressing the receptor CXCR ${ }^{1}$. Enhanced accumulation of neutrophils in the pocket epithelium and adjacent connective tissue of patients with chronic periodontitis and with generalized aggressive periodontitis (GAP)s was associated with the upregulation of IL8, intercellular adhesion molecule-1, IL-1b and TNF-a expression, which related to the severity and activity of generalized aggressive periodontitis. ${ }^{24}$ Anne Havemose-Poulsen in 2005 compared Cytokine Profiles in Peripheral Blood and Whole Blood Cell Cultures Associated With Aggressive Periodontitis, J uvenile idiopathic Arthritis, and Rheumatoid Arthritis, found that two anti-inflammatory cytokines, I L 10 and IL IRa were significantly elevated in GAP patients and patients with aggressive periodontitis and type of arthritis presented with similar components of blood cytokine profiles distinguishing them from individuals free of disease. I nterestingly, it has recently been shown that infection of human macrophages with $A$. actinomycetemcomitans (Aa), a bacterium associated with certain forms of aggressive periodontitis, results in the profound release of activel L-1b, an effect considerably larger than that induced by LPSand not associated with enhanced secretion of interleukin-6 or TNF. The effect is mainly dependent on the leukotoxin from $A$. actinomycetemcomitans

\section{Interleukin Polymorphisms and Periodontitis}

The systemic immune response, genetic and environmental factors also affect the risk of developing periodontitis. In recent years, studies have demonstrated that periodontitis is associated with elevated levels of a variety of inflammatory biomarkers. F urthermore, genetic variants of some cytokines confer susceptibility to periodontitis. ${ }^{3}$ As it is accepted that the immune system plays an important role in the pathogenesis of periodontitis, most genes that are considered to be responsible for the development of periodontitis are also linked to the immune response. These include the genes that affect the expression of ILI, IL-6, TNF-a, and IL10, E-selectins, F c-gamma receptor, CD 14, toll-like receptors, caspase recruitment domain 15 and vitamin D receptor.1 Polymorphisms arises as result of insertion and deletion in nucleotide sequence. Genotype polymorphisms have also been associated with disease diagnosis, severity and presence of subgingival bacteria. IL8 and IL6 investigated for the relationship between periodontopathic bacteria (Aa $\& \mathrm{Pg})$ and bleeding on probing which shows that association is found in both aggressive and severe form of chronic periodontitis.

\section{IL-1 Gene Polymorphism}

IL-1 gene cluster is located on chromosome 2 . The first study that reported polymorphism for I L1 gene in relation to periodontitis was presented by Korman et al, in Caucasians. He concluded that IL1 composite genotype could be considered a putative severity factor for periodontitis in Caucasians. Sensitivity and specificity of IL-1 "Genotype positive" model was depicted by Kornman et al, 1997. 'Anne Havemose - Poulsen et al. demonstrate that in localized aggressive periodontitis patients, allele 2 of IL - 1 RN VNTR(variable no. of tandem repeats) was associated with significantly higher levels of IL -1a, 6, 10 and TNF - $a$, whereas allele 2 of IL - Ip +3954 was associated with significantly lower levels of the same cytokine.

\section{L-4 Gene Polymorphism}

IL -4- polymorphism was at the promoter sequence $590 \mathrm{C} / \mathrm{T},-33 \mathrm{C} / \mathrm{T}$ and intron 3 . VNTR of IL4 acted in a cooperative fashion andresulted in high production of IL 4. In 2008, Stefan Reichert et al studied the expression or IL-12 R p2 molecule in a crucial regulatory factor in the $T$ helper type differentiation of $\mathrm{T}$ cells. They found that single nucleotide polymorphism of the flanking region of IL -12RB2 leads to a very weak cellular immune response. They reported that the frequencies of variant alleles of IL 12 RB2 weresignificantly higher in aggressive periodontitis patients.

\section{L-6 Gene Polymorphisms}


Shao et al 2009, in the meta-analysis indicate that the IL $-6,-174 \mathrm{G}$ allele could not modify the risk of chronic periodontitis, but increased risk of aggressive periodontitis. And -572 C/G polymorphism is associated with the pathogenesis of periodontitis, as it predisposes to either chronic or aggressive periodontitis.

\section{L-10 Gene Polymorphisms}

IL-10 gene is located on chromosome 1 , in a cluster with closely related IL-genes I L-19, - 24. IL10 has an inhibitory effect on IL-1a, IL-1b,TNF-a, I L-6,8 and 12. Functional disturbances in I L-10 due to genetic polymorphisms could be detrimental to host tissue and linked to periodontal disease susceptibility.

\section{Implant Failure And Interleukin Polymorphism}

Regarding the timing of implant failure, it can be classified as early when osseointegration fails to occur, or late when the achieved osseointegration is lost after a period of function. I nfection, overheating and impaired healing are the main factors associated with early failure of dental implants. Of these, surgical trauma, a consequence of implant insertion, initiates a local inflammatory response that includes the release and activation of a variety of cytokines and growth factors. This local factor production determines the quality of bone formation or the formation of fibrosis. Increased levels of bone resorptive interleukins, such as IL-1, might stimulate an excessive inflammatory response, affecting osseointegration success.

A few studies have analyzed the relationship between interleukin-1 genepolymorphisms and implant failure. Wilson \& Nunn (1999) werethe first to study the relationship between implant loss and the interleukin-1 composite genotype reported by Kornmanet at (1997) [allele Tat interleukin- I A (889) and at interleukin-1B [p3953) loci]. Their analysis failed to provide a positive correlation, but these results might have been influenced by variables, such smoking and the existence of late and early failure implants in the same sample. Rogers et al. (2002) also found no association between the same. Campos et al 2004 also showed that polymorphism in the interleukin-1 RN (intron 2), interleukin- 1B (511, p3953) and interleukin-1A (889) genes were not associated with early implant failure in a nonsmoking Brazilian population.

\section{Interleukins as Diagnostic Marker}

The biochemical assessment of periodontal disease can be accomplished using several approaches. The most practical and leastinvasive, involves analysis of biologic fluids that are derived from the periodontal tissues or contain specific mediators that are present as a result of periodontal disease. The biologic fluids that have been studied to understand the nature of destructive periodontitis and to identify potential diagnostic markers of active disease include serum (blood), gingival fluid, and saliva.

\section{Blood}

Studies of serum antibody levels to periodontal bacteria were among earliest investigations demonstrating that a humoral immune response occurs in patients with periodontitis. More recent studies have demonstrated that patients with periodontitis have el evated antibody titers to subgingival pathogens. The levels of inflammatory cytokines (ie, IL-6) and general markersof inflammation (ie, C-reactive protein) have been shown to be elevated in the blood of patients with periodontitis. Nevertheless, serum markers of periodontitits, or of inflammation, are not currently used as diagnostic tests for periodontitis. ${ }^{25}$

\section{Gingival Crevicular Fluid}

GCF is a serum transudate, or more commonly inflammatory exudates, that emanates from the gingival crevice and can becollected from the crevice orifice. GCF has been analysed for diagnostic purposes. I ts constituents are derived from a variety of sources including host as well as from microorganisms in the subgingival and supragingival plaque. The collection and analysis of GCF samples provides a non-invasive means to assess the pathophysiological status of the periodontium in a site-specific manner. According to Armitage (2004), more than 65 GCF constituents have been evaluated as potential diagnostic markers of periodontal disease progression. These markers can be divided into three groups: host-derived enzymes and their inhibitors, inflammatory mediators and host-response modifiers, and byproducts of tissue breakdown. The inflammatory cytokines in particular IL-1b, may play an integral role in the etiology of periodontal disease. Lieu et al (1996) demonstrated that with an increase in gingival index and probing, there was a corresponding increase in IL-1b in both the gingival tissue and GCF. Engebretson et al through a longitudinal study suggested that GCF IL-1b expression is genetically influenced and not solely a result of local clinical parameters. Also, a GCF 
level of 1 L 8 was found to be higher in periodontal diseases and was influenced by local IL 1 beta activities.$^{26}$

\section{Interleukins as Anti-Inflammatory and Antiresorptive Therapy}

As inflammatory cytokines are involved in inflammatory diseases associated with bone loss and have therefore become logical targets for the development of therapeutic agents. One of the first cytokines to be targeted was IL-1 as a result of its key regulatory role in bone resorption in diseases such as rheumatoid arthritis and periodontitis. In addition, agents targeting IL-3,6,15,12 and 23 have been studied. These anti-cytokine agents provide new opportunities to modulate host responses in inflammatory diseases. In particular, most seem to influence the secondary effects of cytokines on RANKL expression and therefore may not influence osteoclast-mediated bone resorption directly. Future efforts in this area, to ensure more effective control of pathologic bone resorption should try to target those cytokines that directly influence osteoclast formation and function. Surprisingly few studies have investigated the effect of interleukin antagonists on periodontitis. One study investigating inflammation and tissue loss in a nonhuman primate model of periodontitis using human soluble interleukin-1 receptor type 1 as an inhibitor of IL-1 reported that the inhibition of I L-1 has a significant effect on the reduction of inflammation, connectivetissueattachment loss and bone resorption .Given the emerging use of these agents as anti-inflammatory and anti-resorptive agents, further investigations in experimental models of periodontitis are arranted. ${ }^{27}$

\section{CONCLUSION}

Interleukins are key modulators of inflammation. They participatein acuteand chronic inflammation in a complex network of interactions. Several cytokines exhibit some redundancy in function and share overlapping properties and structure.Theseplay an important role in a number of different physiologic processes, but if expressed inappropriately, they also induce pathology. U nder pathologic conditions such as those that occur in periodontal disease, the balance between pro- and anti-inflammation is directed towards proinflammatory activity .In periodontal tissue destruction three proinflammatory cytokines, IL-1, IL-6, and TNF-a, appear to have a central role.

Better understanding of the pathways regulated by interleukins will allow the identification and/or development of agents for improved modulation of the inflammatory response for the treatment of periodontitis autoimmune, infectious, and neoplastic diseases.

\section{References:}

1. Carol A, Feghali, Timothy NI. Wright. Cytokines in acute and chronic in M.D. Frontiers in Bioscience 1997; dl2-26.

2. Okada H. and Murakami S. Cytokine Expression in Periodontal Health and Disease; Crit Rev Oral viol Med 1998; 9(3):248-66.

3. Bosshardt DD, Lang N P. The junctional epithelium: from health to disease. J Dent Res 2005; 84:9-20.

4. Graves DT and Cochran D. The contribution of interleukinI and tumor necrosis factor to periodontal tissue destruction. J Perioclontol 2003; 74:391-401.

5. Pranay D Khare and Meenakshi Khare. Cytokines: Physiology and Clinical Relevance Neurosciences 2010; 17.

6. Cytokine responses against periodontal infection: protective and destructive roles Periodontology 2000 2010; 52:163-206.

7. Bartold P NI, Walsh LJ , Narayanan S. Molecular and cell biology of the gingiva. Periodontal 2000; 24:28-55.

8. Palmqvist $P, L$ undberg $P$, L undgren $I$, Hannstron $L$, Lerner $\mathrm{U} \mathrm{H}$. I L-b and TNF-a regulate I L- 6 type cytokines in gingival fibroblasts. J Dent Res 2008; 87:558-63.

9. Nurcan Buduneli and Gol Aeilla. Are inflammatory cytokines potentia mediators of phenytoin induced gingival overgrowth? Truk j Med Sci 2001; 3:41-6.

10. J ohn J. Taylor. Cytokine regulation of immune responses to Porphyromonas gingivalis. Periodontology 2000 2010; 54:160-94.

11. Masanori Koide, Saya Kinugawa, Naoyuki Takahashi, and Nobuyuki Udagawa. Osteoclastic bone resorption induced by innate immune responses. Periodontology 2000 2010; 54:235-46.

12. Osorio F, LeibundGut-Landmann S, Lochner M, LahlK, Sparwasser T, Eberl G, Reise Sousa C. DC activated viadectin-1 convert Treg into IL-17 producers. Eur J Immunol 2008; 38:3274-81.

13. Gemmell E, Yamazaki K, Seymour GJ. The role of T cells in periodontal disease: homeostasis and autoimmunity. Periodontol 2000 2007; 43:14-40.

14. Gemmell E, Yamazaki K, Seymour GJ. Destructive periodontitis lesions aredetermined by the nature of the lymphocytic response. Crit Rev Oral Biol Med 2002; 13:1734.

15. Gemmell E and Seymour GJ. Modulation of immune responses to periodontal bacteria. Curr Opin Periodont 1994; 94:28-38.

16. Lappin DF, MacLeod CP, Kerr A, Mitchell T, Kinane DF Anti-inflammatory cytokine I L-10 and T cell cytokine profile in periodontitis granulation tissue. Clin Exp Immunol 2001; 123:294-300.

17. Trevilatto PC, Scarel-Caminaga RM, de Brito RB, de Souza AP. Polymorphism at position 174 of I L- 6 gene is associated with susceptibility to chronic periodontitis in a Caucasian Brazilian population. . I Clin Periodontol 2003; 30(5):43842. 
18. Sigusch $B$, Klinger $G$, Glockmann $E$, and Simon HU . Earlyonset and adult periodontitis associated with abnormal cytokine production by activated $\mathrm{T}$ Iymphocytes. J Periodontol 1998; 69:1098-104.

19. Shinsuke Onishi, Kiyonobu Houma, Simang Liang, Panagiota Stathopoulou, Denis Kinane. Toll-Like Receptor 2-Mediated I nterleukin-8 Expression in Gingival E pithelial Cells by the Tannerellafirsythia Leucine-Rich Repeat Protein BspA. Infection and I mmunity 2008; 98-205.

20. Gemmell E, Seymour GJ . Cytokine profiles of cells extracted from humans with periodontal diseases. J Dent Res 1998; 77:16-26

21. Beklen A, Ainola M, Hukkanen M, Gunrgan C, Sorsa T, Konttinen YT. MMPs, IL- 1, and tumor necrosis factor are regulated by IL-17 in periodontitis. J Dent Res 2007; 86:34751.

22. Graves DT and Cochran D. The contribution of interleukinI and tumor necrosis factor to periodontal tissue destruction. J Perioclontol 2003; 74:391-401

23. Eija IKorpelainen, J ennifer R Gamble, Mathew A Vadas and Angel F Lopez. I L-3 receptor expression, regulation and function in cells of the vasculature Immunology and Cell Biology 1996; 74: I-7.

24. Yu J J, Ruddy NU, Conti FIR, Boonanantanasam K and Gaffer SL. The interleukin-17 receptor plays a genderdependent role in host protection against Porphyromonas gingivalis induced periodontal bone loss. I nfect I mmun 2008; 76:4206-13.

25. Liu RK, Cao CF, Meng HX, Gao Y. Polymorphonuclear neutrophils and their mediators in gingival tissues from generalized aggressive periodontitis. J Periodontal 2001;72: 1545- 53.

26. Loos BG, Craandijk J, Hoek FJ , et al. Elevation of systemic markers related to cardiovascular diseases in the peripheral blood of periodontitis patients. J Periodontol 2000: 71(10):I528-34.

27. Zia Al, Khan Si, Bey Al, Gupta NDI, Mukhtar-Un-Nisar. Oral biomarkers in the diagnosis and progression of periodontal Diseases. Biology and Medicine 2011;3(2):4552.

28. Bochi J A, Wara-aswapati N, Auron PE. Interleukin I signal transduction-current concepts and relevance to periodontitis. Dent Res 2001: 80(2):400-7.

29. Leigh W Kent, Firoz Rahemtulla, Richard D Hockett. Effect of Lipopolysaccharide and Inflammatory Cytokines on Interleukin-6 Production by Healthy Human Gingival Fibroblasts Infection and I mmunity 1998; 66(2): 608-14.

30. R.G. Goodwin, S. Lupton, A. Schmierer, K.J . Hjerrild, R. J erzy, W. Clevenger, S. Gillis, D. Cosman and A.E. Namen. Human interleukin-7: molecular cloning and growth factor activity on human and murine B-lineage cells. Proc Nati Acad Sci 1989; 86:302-6.

31. Reddy BH, Jayakumar ND, Akula SR, Sharma R, Kaarthikeyan C, Sankari. Analysis of association between TLR4 Asp299Gly and Thr399lle gene polymorphis ms and chronic periodontitis in a sample of south Indian population. I Indian Soc Periodontol 2011; 15(4):366-70.

32. Baggiolini et al., Chemokines in pathology and medicine J Internal Med 2001; 250:91-104.
33. Essential involvement of interleukin-8 (IL-8) in acute Inflammation. J ournal of Leukocyte Biology : Volume 56.

34. Sudha Agarwal, Chart S Chandra, Nicholas P Piesco, Herman H Langkamp, Lathe Rowen, Coskun Raran. Functional Role of Interleukin I in Periodontal Disease: Induction of Interleukin I Production by Racteroides gingivalis Lipopolysaccharide in Peritoneal Macrophages from $\mathrm{C} 3 \mathrm{H} / \mathrm{HeN}$ and $\mathrm{C} 3 \mathrm{H} / \mathrm{HeJ}$ Mice. Infection and Immunity 1985; 262-70.

35. Graves DT and Cochran D. The contribution of interleukin1 and tumor necrosis factor to periodontal tissue destruction. J Periodontol 2003; 74:391-401.

36. Gemmell E, Yamazaki K, Seymour GJ . The role of T cells in periodontal disease: homeostasis and autoimmunity. Periodontol 2000 2007; 43:14-40.

37. Gemmell E, Yamazaki K, Seymour GJ. Destructive periodontitis lesions are determined by the nature of the Iymphocytic response. Crit Rev Oral Biol Med 2002; 13:1734.

38. Cunha FQ, Poole S, Lorenzetti BB, Veiga FH, Ferreira SH Cytokine-mediated inflammatory hyperalgesia limited by interleukin-4 British J ournal of Pharmacology 1999; 126:4550.

39. Fujita T, Ashikaga A, Shiba $H$, Kajiya M, Kishimoto A, Hirata R, Tsunekuni N, Hirono C, Kawaguchi H, Shiba $Y$, Kurihara $\mathrm{H}$. I rsogladine maleate counters the interleukinI b- induced suppression in gap-junctional intercellular communication but does not affect the interleukin-lbinduced zonula occludens protein- I levels in human gingival epithelial cells. J Periodont Res 2008; 43:96-102.

40. Sudha Agarwal, Charu S Chandra, Nicholas P Piesco, Herman H Langkamp, Lathe Rowen, Coskun Raran. Regulation of Periodontal Ligament Cell Functions by Interleukin-Ib. Infection and I mmunity 1998; 932-7.

41. Hosokawa Y Hosokawa I, Ozaki K, Nakae H, IVlatsuo T. Cytokines differentially regulate CXCLIO production by interferon-cestimulated or tumor necrosis factor a stimulated human gingival fibroblasts. J Periodont Res 2009; 44:225-31.

42. Steinberg $T$, Dannewitz B, Tomakidi P, Hoheisel J D Munssig $E$, Kohl A, Nees M. Analysis of interleukin- Ibmodulated mRNA gene transcription in human gingival keratinocytes by epithelia-specific cDNA microarrays. J Periodont Res 2006; 41:426-46.

43. Sung Woo Lee and Yun Sik Hong. Anti-inflammatory effects of I L-4 and I L-10 on Human Polymorphonucl ear Leukocytes. J Korean Med Sci 2002; 17:7-14

44. Rawlinson A, Grummitt Walsh TF, and Douglas CWI Interleukin I and receptor antationist levels in gingival crevicular fluid in heavy smokers versus non-smokers. J Periodontol 2003; 30:42-8.

45. Lester SR, Rain J L, Serio FG, and J ohnson R.R. Relationship between the gingival sulcus depth and interleukin- I isoform concentrations within the adjacent gingival tissue. J Periodont Res 2009; 44:323-9.

46. Rachna Kaushik, R. K. Yeltiwar, and Kumar Pushpanshu. Salivary Interleukin-IReta Levels in Chronic Periodontitis Patients Before and After Periodontal Phase-I Therapy and Healthy Controls A Case-Control Study. J ournal of Periodontology 2011; 82(9):1353-9. 